\title{
Erratum to: Acupuncture for menopausal vasomotor symptoms: study protocol for a randomised controlled trial
}

Marie Pirotta ${ }^{1 *}$, Carolyn Ee ${ }^{1}$, Helena Teede ${ }^{2,3}$, Patty Chondros ${ }^{1}$, Simon French ${ }^{4,5}$, Stephen Myers ${ }^{6}$ and Charlie Xue $^{7}$

\section{Erratum}

After the publication of this work [1], it was brought to our attention that the time for patient follow-up specified in the 'Statistical methods' section of the protocol was incorrect; follow-up will continue for six months after the end of treatment, not 12 months as stated in the original published version.

\footnotetext{
Author details

'Department of General Practice, University of Melbourne, 200 Berkeley St, Carlton 3053, Victoria, Australia. ${ }^{2}$ Monash Centre for Health Research and Implementation, School of Public Health and Preventive Medicine, Monash University, Melbourne, Australia. ${ }^{3}$ Diabetes and Vascular Medicine Unit, Monash Health, Melbourne, Australia. ${ }^{4}$ School of Rehabilitation Therapy, Queen's University, Ontario, Canada. ${ }^{5}$ Faculty of Health Sciences, Ontario, Canada. ${ }^{6}$ Division of Research, NatMed-Research Unit, Southern Cross University, Lismore, Australia. ${ }^{7}$ School of Health Sciences, RMIT University, Melbourne, Australia.
}

\section{References}

1. Pirotta M, Ee C, Teede H, Chondros P, French S, Myers S, et al. Acupuncture for menopausal vasomotor symptoms: study protocol for a randomised controlled trial. Trials. 2014;15:224.

\footnotetext{
*Correspondence: m.pirotta@unimelb.edu.au

'Department of General Practice, University of Melbourne, 200 Berkeley St, Carlton 3053, Victoria, Australia

Full list of author information is available at the end of the article
}

Submit your next manuscript to BioMed Central and take full advantage of:

- Convenient online submission

- Thorough peer review

- No space constraints or color figure charges

- Immediate publication on acceptance

- Inclusion in PubMed, CAS, Scopus and Google Scholar

- Research which is freely available for redistribution 